\title{
Olivar. Despedida y saludo
}

Cita sugerida: Macciuci, R. (2020). Olivar. Despedida y saludo.

Olivar, 20(32), e091. https://doi.org/10.24215/18524478e091

Coincidiendo con los veinte años de la creación de Olivar, resultado de la colaboración asociada de las profesoras al frente de las cátedras de Literatura Española I y Literatura Española II, tomo la pluma permítaseme la varias veces arcaica sinécdoque- no para invitar, como entonces, a los que serían, con distintas funciones, imprescindibles compañeros de viaje, sino para escribir unas líneas de despedida cuando la publicación ha pasado a manos de una generación más joven.

Me hubiera gustado entregar antes el testigo, pero fue necesario extender la singladura -perdón por la clásica alegoría - para dejar mejor precisados en el mapa algunos puntos clave del trayecto iniciado junto con el siglo, por los que tuve que luchar para que no se desdibujaran.

Ignoro si es de rigor realizar en estos casos una reseña de lo actuado; en todo caso, no es mi propósito en este espacio. En su lugar, invito a quienes leen a recorrer y detenerse en los índices, los números monográficos, los dosieres, los equipos que se han sucedido a través de los 20 volúmenes publicados; es la mejor relación que puedo imaginar. Según consta en ese mismo archivo al que aludo, durante dos décadas he sido secretaria, codirectora y directora, rótulos, a mi modo de ver, no muy certeros ni demasiado veraces (en todo caso, paradójicamente, el orden inverso sería, de facto, más representativo de mi estatuto formal).

Por dicha razón, prefiero se me reconozca simplemente como hacedora de Olivar. Persuadida -aunque la literatura española es una, una la literatura hispánica, y una la literatura mundial- de que el conocimiento científico requiere concentración y especificidad, desde mi lugar de fundadora corresponsable de la publicación pero experta en los temas abarcados por la asignatura Literatura española II -esto es, el extenso lapso que media entre el Barroco y el siglo XXI- de la que soy profesora titular, trabajé de manera sostenida para que la excelencia fuera meta y horizonte de la revista. En forma constante, muchas veces invisible, sostuve el rumbo, exploré nuevas vías y sorteé no pocos atolladeros.

A quienes me acompañaron en este hacer y quehacer -a veces calladamente- en los decisivos prolegómenos y primeras millas; o en la dilatada andadura, que incluyó la cátedra y la investigación como instrumentales básicos, les transmito mi más profundo reconocimiento. Sean los que recalaron sin retorno en otros puertos, 
sea la indispensable savia nueva recién incorporada, sea, en particular, el equipo de Literatura española II que continuó sin desmayo en dispares, a veces adversas circunstancias; todos serán siempre objeto de toda mi gratitud por haber compartido el periplo.

Es sabido que obtener buenos frutos conlleva esfuerzos no exentos de discordancias y contratiempos. Con un auspicioso y cordial saludo al nuevo director y a todos los integrantes del nuevo plantel -más que nuevo, remozado- les brindo mi total apoyo para lo que fuere menester y les deseo la mejor de las travesías, con la plena confianza de que gracias a la experiencia acumulada, unida a sus predecibles redoblados esfuerzos, evitarán escollos, navegarán con bonanza y lograrán mejores frutos aún.

Raquel Macciuci

La Plata, 22 de octubre de 2020 